\title{
SOSIALISASI PEMBUATAN PUPUK ORGANIK CAIR DAN PENERAPAN PEMASARAN PRODUK UMKM MELALUI MEDIA SOSIAL DI ERA COVID-19
}

\author{
Dewi Diah Fakhriyyah*, Sholihatun, Zulfa Afifah \\ Fakultas Ekonomi dan Bisnis, Universitas Islam Malang \\ *korespondensi email: dewi_df@unisma.ac.id
}

\begin{abstract}
ABSTRAK
Pembuatan pupuk kompos dari limbah rumah tangga merupakan upaya pemanfaata pengurangan limbah yang dijadikan kompos untuk menjaga kelestarian lingkungan, sekaligus untuk mengurangi biaya pengeluaran. Desa sumbersekar RT.04 terdapat UMKM florist dan tanaman hidropnik, karena warga masih memiliki pengetahuan yang rendah tentang pengolaan limbah yang menghasilkan produk yang bernilai, untuk. Itu Kami melakukan sosialisasi tentang pembuatan pupuk organik untuk membuat pupuk cair dari limbah domestik. Penggunaan pupuk organic cair ini dalam jangka panjang dapat mengurangi limbah rumah tangga dan meningkatkan kesuburan tanaman masyarakat serta mengurangi pengeluaran pembelian pupuk. Pupuk organik yang sudah jadi bisa dijual untuk menambah pendapatan dan juga dapat digunakan sendiri untuk menyuburkan produk tanamannya pada pelaku UMKM Florist. Permasalahan mitra adalah belum memahami pembuatan pupuk organik cair dan masih awam dalam pembuatan social media marketing untuk meningkatkan penjualan. Oleh karena itu, kami melakukan sosialisasi dan edukasi tentang pemahaman pupuk organic cair dan mempraktekkannya langsung serta sosialisasi pemanfaatan berbagai social media untuk pemasaran, tak lupa kami juga sosialisasikan membuat iklan yang menarik. Kegiatan ini diharapkan dapat memberi manfaat pada pelaku UMKM Florist untuk mengurangi pengeluaran pupuk dan menambah pemasukan melalui pemanfaatan social media.
\end{abstract}

Kata Kunci: pupuk organik; mikro organisme; UMKM; sosial media marketing

\section{PENDAHULUAN}

Indonesia sebagai negara agraris yang sebagaian penduduknya melakukan kegiatan pertanian tentu membutuhkan pupuk untuk menyuburkan tanah dan tanaman. Pupuk adalah kunci dari kesuburan tanah karena berisi satu atau lebih unsur untuk menggantikan unsur yang habis terisap tanaman. Jadi, memupuk berarti menambah unsur hara kedalam tanah dan tanaman. Pupuk merupakan material yang ditambahkan pada media tanam atau tanaman untuk mecukupi kebutuhan hara yang diperlukan tanaman sehingga mampu berproduksi dengan baik (Dwicaksono,2013).

Sampai saat ini telah banyak berbagai jenis pupuk kimia. Namun kita lupa bahwa disekitar kita banyak terdapat bahan yang dapat dimanfaatkan untuk pembuatan pupuk khususnya pupuk organik. Terutama di saat seperti ini yang sedang pandemi maka kita perlu untuk menekan pengeluaran dan memanfaatkan bahan disekitar kita, misalnya membuat pupuk organik. 
Penggunaan pupuk organik alam yang dapat dipergunakan untuk membantu mengatasi kendala produksi pertanian yaitu Pupuk Organik Cair. Pupuk organik cair dapat memperbaiki sifat fisik, kimia, dan biologi tanah, membantu meningkatkan produksi tanaman, meningkatkan kualitas produk tanaman, mengurangi penggunaan pupuk anorganik dan sebagai alternatif pengganti pupuk kendang (Noerhayati \& Sulo, 2018; Dewanto et al., 2017). Pupuk cair merupakan larutan mudah larut berisi satu atau lebih pembawa unsur yang dibutuhkan tanaman. Kelebihannya adalah dapat memberikan hara sesuai dengan kebutuhan tanaman. Selain itu, pemberiannya dapat lebih merata dan kepekatannya dapat diatur sesuai dengan kebutuhan tanaman (Indrakusuma, 2010). Kelebihan dari pupuk organik cair juga adalah dapat secara cepat mengatasi defesiensi hara, tidak bermasalah dalam pencucian hara dan mampu menyediakan cepat. Dibandingkan dengan pupuk anorganik, pupuk organik cair umumnya tidak merusak tanah dan tanaman walaupun digunakan sesering mungkin (Nugroho, 2012).

Sebagian masyarakat masih menggunakan pupuk kimia karena itu kami menyarankan kepada Ibu-Ibu PKK atau pelaku UMKM untuk melakukan produksi pupuk organik dengan skala sedang, supaya sebagian bisa dipakai pribadi dan sebagian bisa didistribusikan kepada para petani Indonesia untuk menggunakan pupuk organik yang lebih ramah lingkungan. Kita tahu bahwa bahan pupuk organik dapat diperoleh dengan mudah dan murah dari sekitar kita yaitu dari sampah rumah tangga berupa sisa bahan makanan seperti sayur dan mayur dan kulit buah. Pemanfaatan pupuk organik untuk menyuburkan tanaman khususnya pada UMKM florist di Desa Sumbersekar, Kecamatan Dau, Kabupaten Malang dapat menjadi salah satu upaya penghematan pengeluaran pupuk, ditambah lagi di masa pandemi yang serba sulit ini. Hasil dari pemanfaatan pupuk organik untuk menyuburkan tanaman pun dapat juga ditunjang dengan penggunaan social media marketing untuk memasarkan produk tanaman yang dijualnya.

Dalam bukunya Evans dan McKee (2013) mengatakan bahwa social media marketing di pratekkan untuk melibatkan pelanggan pada lokasi social online dimana para pelanggan secara alami menghabiskan waktu. Menurut Santoso (2017) pemasaran sosial media merupakan bentuk pemasaran yang dipakai untuk menciptakan kesadaran, pengakuan, ingatan dan bahkan tindakan terhadap suatu merek, produk, bisnis, individu, atau kelompok baik secara langsung maupun tidak langsung dengan menggunakan alat dari web sosial seperti blogging, microblogging, dan jejaring sosial.

Dengan adanya social media marketing memudahkan para pelaku usaha untuk berinteraksi dengan pelanggannya secara online. Biaya yang dikeluarkan tidak terlalu besar dan tidak ada batasannya waktu selama tersambung dengan internet. Media sosial berperan saat pemasaran kegiatan perusahaan membentuk hubungan individu dengan pelanggan dan memberi perusahaan peluang untuk mengakses pelanggan (Kelly et al., 2010). Dengan generalisasi media sosial di seluruh masyarakat, para peneliti telah mempelajari penggunaan media sosial dengan menyelidiki mengapa mereka menggunakan media sosial, berapa banyak waktu yang mereka gunakan, dan jumlah digunakan dalam periode waktu tertentu (Bolton et al., 2013).

Pelaku UMKM florist di desa Sumbersekar RT.04, Kecamatan Dau, Kabupaten Malang yang masih belum memahami pembuatan pupuk organik dan juga masih awam dalam melakukan penjualan menggunakan social media marketing membuat kami ingin memberikan sosialisasi atas dua hal tersebut.

Tujuan dilakukannya Sosialisasi untuk menambah wawasan masyarakat tentang teknik pembuatan pupuk organik supaya lebih menghemat pengeluaran serta membantu 
masyarakat dalam melestarikan lingkungan, dan masyarakat bisa menjalani gaya hidup sehat terutama dimasa pandemi ini. Selain itu pupuk organik yang sudah jadi bisa di perjual belikan sebagai tambahan omset UMKM.

Kemudian tujuan diadakannya sosialisasi pemasaran menggunakan media sosial dapat menambah pengetahuan para pelaku UMKM supaya bisa memahami lebih dalam tentang media sosial, mengetahui cara bagaimana membuat strategi pemasaran menggunakan social media untuk meningkatkan penjualannya.

\section{METODE}

Fokus utama kami pada proyek ini adalah salah UMKM florist dan tanaman hidroponik di Desa Sumber Sekar, Kecamatan Dau, Kabupaten Malang. Metode yang kami gunakan adalah ceramah dan praktek. Kami melakukan sosialisasi dan edukasi yang direncanakan sesuai rencana kerja kurang lebih selama 4 minggu dengan menggunakan protokol kesehatan. Adapun pembahasan dalam proses sosialisasi yang kami lakukan adalah sebagai berikut:

1. Sosialisasi pemahaman mengenai pupuk organik

2. Sosialisasi pemahaman dan tata cara mengenai penggunaan sosial media untuk menunjang proses pemasaran.

3. Praktik pembuatan pupuk organik

4. Sosialisasi membuat iklan semenarik mungkin agar menarik perhatian konsumen

Sosialisasi yang kami lakukan langsung di gazebo pintar yang sasaran utamanya ibuibu PKK yang sekaligus menjadi pelaku UMKM. Kami berharap dapat membantu para pelaku UMKM tersebut untuk melancarkan pemasaran produknya serta mengurangi biaya pengeluaran di era pademi.

\section{HASIL DAN PEMBAHASAN}

Tahapan pertama sosialisasi adalah pemanfaatan potensi lingkungan sekitar berupa sampah organik sisa untuk digunakan sebagai pupuk organik. Dalam pembuatan kompos/ pupuk organik ini, menggunakan sampah organik di sekitar lingkungan RT 04 / RW01, antara lain sayur mayur, bonggol pisang, dan kotoran sapi. Metode pengomposan yang digunakan adalah aerobik di permukaan tanah. Selanjutnya kami menjelaskan peran pupuk organik dalam sifat biologis tanah adalah sumber energi dan makanan bagi flora mikroba dan mesenkim tanah. Ketika tercukupinya bahan organik, aktivitas organisme tanah meningkat sebesar, sehingga meningkatkan ketersediaan nutrisi, siklus nutrisi tanah, mikroorganisme tanah dan mikroorganisme seperti cacing tanah, semut putih.

Tahapan kedua kami melakukan sosialisasi penggunaan social media marketing untuk membantu proses penjualan karena pemilik UMKM Green Florist di Desa Sumbersekar masih memiliki kesulitan dalam mengaplikasikan sosial media untuk mendukung proses pemasaran produk. Pemilik UMKM ini masih belum mengetahui bagaimana cara mempromosikan tanaman bunga agar dikenal masyarakat luas dengan menggunakan teknologi modern. Kami menjelaskan bahwa pemasaran menggunakan media sosial adalah jenis pemasaran digital terbaru dan social media marketing saat ini semakin populer. Social media yang kami perkenalkan dan tunjukkan cara kerjanya adalah Facebook, Twitter, Instagram, YouTube, TikTok, Telegram. Kami memilih sosial media tersebut karena peningkatan penggunanya tinggi serta familiar pada kalangan masyarakat awam.

Tahapan ketiga pada program kerja ini adalah melakukan pengarahan bagaimana cara membuat pupuk organik. Uji coba dengan menggunakan alat drum plastik yang tersedia secara komersial. Kemudian menggunakan kawat jarring sebagai penyangga karena sudah berlubang-lubang kecil, sehingga hasil pupuk cair dapat diturunkan ke bagian bawah partisi. 
Setelah desain alat selesai, langkah selanjutnya adalah menguji alat. Bahan yang dibutuhkan antara lain sampah rumah tangga yang sudah dipotong kecil-kecil atau sisa makanan, larutan gula, air, dan bioaktivator EM4 (mikroorganisme efektif. Masukkan sampah rumah tangga ke dalam ember yang sudah dibuat. Setelah sampah masuk, tambahkan air, larutan gula dan Bioaktivator EM4 Mikroorganisme yang efektif) memiliki bahan-bahan tertentu. Setelah semua bahan dimasukkan, drum disegel. Proses penguraian ini memakan waktu kurang lebih 1-2 minggu, tergantung sampah rumah tangga yang terkandung.

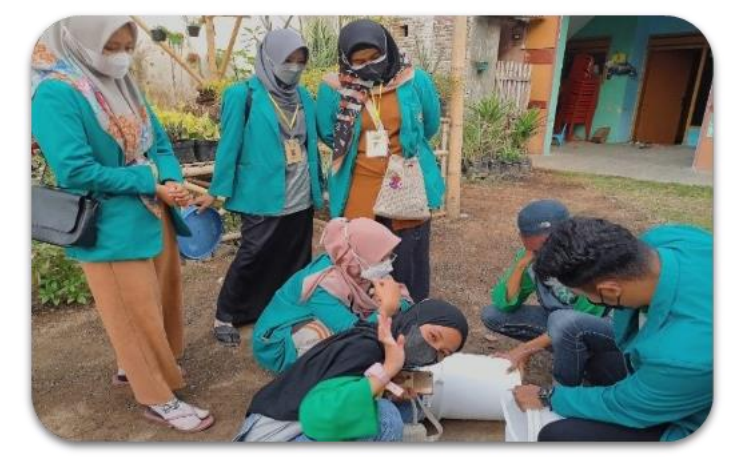

Gambar 1. Pembuatan sekat serta pelubangan ember

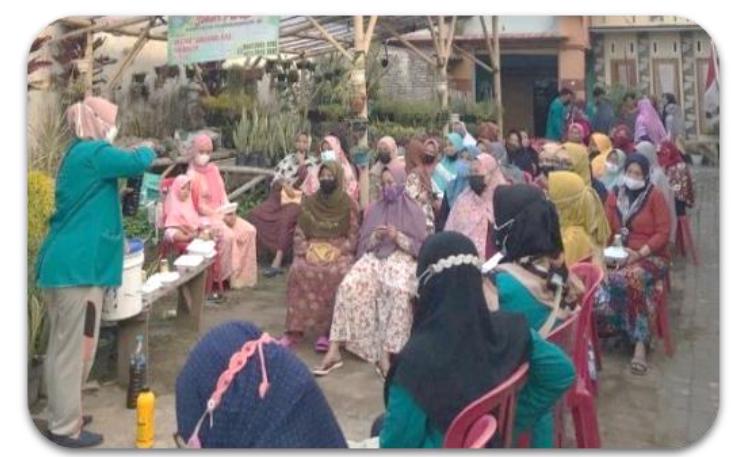

Gambar 2. Proses sosialisasi tentang pupuk organik serta proses pemaparan cara pembuatan pupuk organik

Tahapan keempat pelaksanaan program kerja ini adalah kami melakukan pengarahan tentang bagaimana penggunaan social media untuk menunjang proses pemasaran. Kami mensosialisasikan bagaimana cara upload produk dan memberikan deskripsi produk untuk setiap sosial media yaitu Facebook, Instagram, TikTok. Selain itu, kami juga mensosialisasikan proses pengiriman produk dengan menggunakan Grab atau Gosend. Kemudian di media sosial, kami mengajarkan untuk membuat akun media sosial dan memperkenalkan pemasaran melalui promosi berbayar, endorsement dan sponsor Instagram, TikTok.

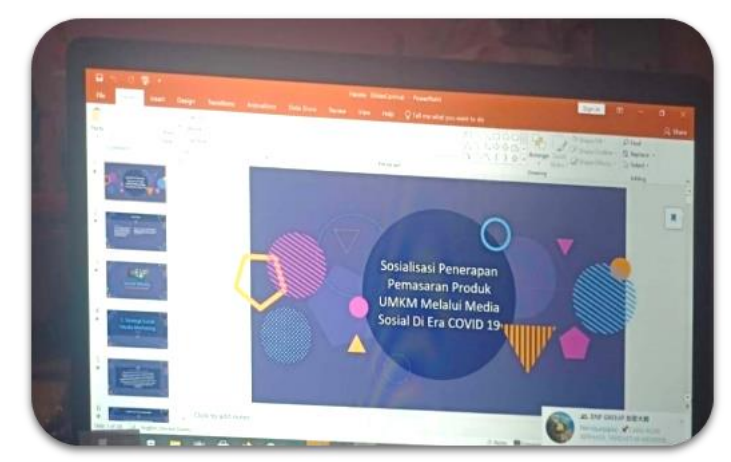

Gambar 3. Materi sosialisasi 


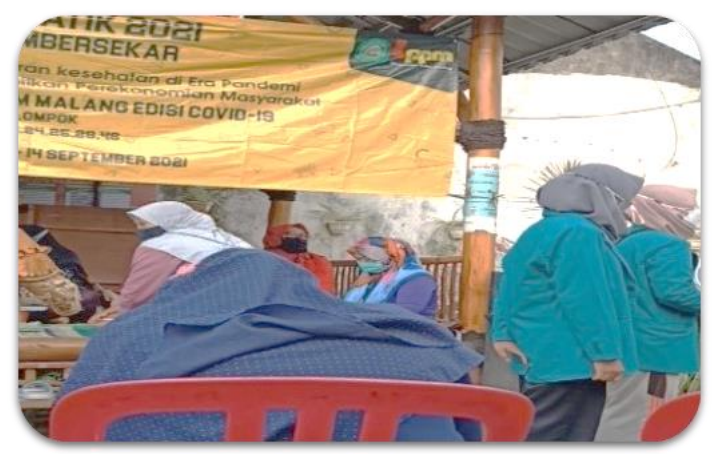

Gambar 4. Proses pemaparan materi serta pengarahan tentang sosial media marketing kepada ibu pkk (pelaku usaha)

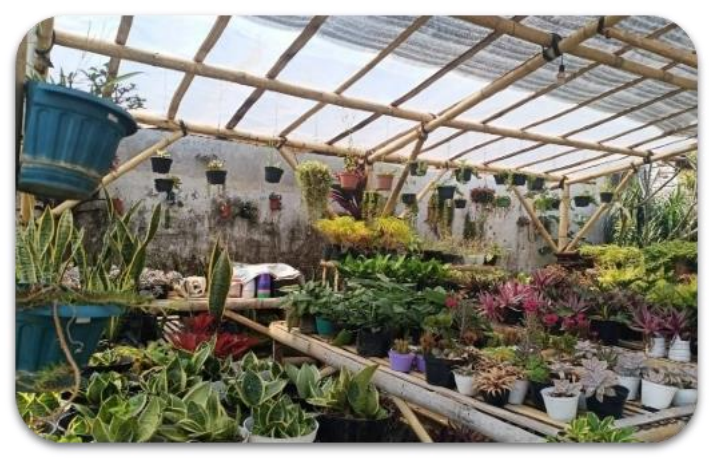

Gambar 5. Produk UMKM

Kami mensosialisasikan dan membuat iklan yang menarik untuk menarik konsumen. Yang perlu dipersiapkan terlebih dahulu adalah kemasan produk yang higienis dan cantik, apalagi saat ini yang paling trendi kemasan yang aesthetic. Produk harus difoto dengan baik dan jelas untuk menarik minat konsumen. Maka diperlu menggambarkan produk dengan bahasa yang jelas, singkat, dan padat dalam iklan, tetapi harus menjelaskan semua informasi produk. Nama produk juga harus sesuai dengan produk yang sebenarnya. Menggunakan strategi pemasaran seperti harga coret, buy 1 get 1, pemotongan ongkir sehingga lebih menarik minat pembeli.

\section{KESIMPULAN}

Kegiatan pengabdian ini memanfaatkan sampah domestik untuk tidak mencemari lingkungan dan membuat media pembuatan pupuk organik cair, pupuk organik cair yang dibuat dapat digunakan untuk meningkatkan kesuburan tanah/tanaman di pekarangan warga. Proses produksi pupuk organik umumnya sudah dipahami masyarakat, ketika tangga sampah domestik disosialisasikan dan dijadikan komoditas berharga, pembuatan alat ini dapat dikembangkan dalam pemilihan bahan baku, terutama bahan yang tahan terhadap asam selama proses pembusukan. Beberapa hal yang kami sosialisasikan adalah pemahaman tentang pupuk organik serta cara pembuatan pupuk dari pemilihan bahan baku sampai menhgasilkan wujud nilainya, selain itu kamu juga memaparkan tentang pengaruh puuk organik terhadap unsur tanah.

Banyak dari pemilik UMKM di Desa Sumbersekar yang memiliki pengetahuan rendah mengenai penggunaan teknologi untuk melakukan pemasaran sehingga kesulitan untuk melakukan pemasaran secara modern melalui sosial media marketing. Dengan menggunakan media sosial sebagai strategi pemasaran, kita dapat memperluas jaringan pelanggan. Oleh karena itu, ini akan memungkinkan lebih banyak orang untuk melihat produk yang biasanya tidak dapat dibeli oleh media periklanan lain. Pada dasarnya, dengan menggunakan media sosial, kami memiliki kesempatan untuk terus tumbuh dan 
membangun hubungan dengan calon pelanggan dengan berpartisipasi aktif dalam aktivitas media. Beberapa hal yang kami sosialisasikan adalah pemahaman mengenai sosial media marketing, tata cara mengenai penggunaan sosial media guna menunjang proses pemasaran, dan sosialisasi membuat iklan yang menarik untuk menarik konsumen.

Beberapa kendala mengenai kegiatan ini adalah faktor waktu dan keterbatasan ruang gerak akibat pandemi Covid-19 ini mengakibatkan kegiatan ini tidak maksimal. Kami berharap untuk pengabdian di masa mendatang dapat memonitor hasil dari sosialisasi yang telah dilakukan dan melakukan pembimbingan atas program kerja ini serta dapat merambah lebih banyak UMKM.

\section{DAFTAR RUJUKAN}

Bolton, R. N., Parasuraman, A., Hoefnagels, A., Migchels, N., Kabadayi, S., Gruber, T., Solnet,D. (2013). Understanding Generation Y and their use of social media: A review and research agenda. Journal of Service Management, 24(3), $245 \mathrm{t} 267$. https://doi.org/10.1108/09564231311326987

Dewanto, F. G., Londok, J. J. M. R., Tuturoong, R. A. V., \& Kaunang, W. B. (2017). Pengaruh Pemupukan Anorganik Dan Organik Terhadap Produksi Tanaman Jagung Sebagai $\begin{array}{lllll}\text { Sumber Pakan. Jurnal } & \text { Zootec, }\end{array}$ https://doi.org/10.35792/zot.32.5.2013.982

Dwicaksono, M.R.B., Suharto, B., L.D. Susanawati. 2013. Pengaruh Penambahan Effective Microorganisme pada Limbah Cair Industri Perikanan Terhadap Kualitas Pupuk Cair Organik. Fakultas Teknologi Pertanian. Universitas Brawijaya. Malang. Diakses pada https://jsal.ub.ac.id/index.php/jsal/article/view/99

Evans, Dave dan Mckee, Jake.2013. Social Media Marketing: The Next Generation Of Business Engagement. Canada: John Wiley \& Sons, Inc.

Indrakusuma. 2000. Proposal pupuk organik cair super alam lestari. PT Surya Pratama Alam.Yogyakarta.

Kelly, et all (2010). Avoidance of advertising in social networking sites: The teenage perspective. Journal of Interactive Advertising, 10(2), 16-27.

Noerhayati, E., \& Sulo, B. D. (2018). IbM Kelompok Peternak Sapi Desa Hadiwarno Kab. Pacitan Dalam Pemanfaatan Energi Alternatif. Jurnal Inovasi Hasil Pengabdian Masyarakat (JIPEMAS), 1(1), 25-28. https://doi.org/10.33474/jipemas.v1i1.1476

Nugroho Panji. 2012. Panduan Membuat Pupuk Kompos Cair. Pustaka BaruPress. Yogyakarta.

Santoso, Amanda Putri. (2017). "Pengaruh konten post Instagram terhadap onlineEngagement. Studi Kasus Pada Lima Merek Pakaian Wanita". Skripsi.Institusi Teknologi Sepuluh November.Vivek, Shiri. Sharon E. Beatty \&Robert

Tim Karya Tani Mandiri. 2010. Pedoman Budidaya Secara Hidroponik. Nuansa Aulia. Bandung. 